\title{
Forecasting flows into and out of apprenticeship training: a scenerio approach
}

Citation for published version (APA):

de Grip, A., Berendsen, H., Borghans, L., \& Dekker, R. (1994). Forecasting flows into and out of apprenticeship training: a scenerio approach. Researchcentrum voor Onderwijs en Arbeidsmarkt, Faculteit der Economische Wetenschappen. ROA Research Memoranda No. 2E https://doi.org/10.26481/umaror.199402E

Document status and date:

Published: 01/01/1994

DOI:

10.26481/umaror.199402E

Document Version:

Publisher's PDF, also known as Version of record

\section{Please check the document version of this publication:}

- A submitted manuscript is the version of the article upon submission and before peer-review. There can be important differences between the submitted version and the official published version of record.

People interested in the research are advised to contact the author for the final version of the publication, or visit the DOI to the publisher's website.

- The final author version and the galley proof are versions of the publication after peer review.

- The final published version features the final layout of the paper including the volume, issue and page numbers.

Link to publication

\footnotetext{
General rights rights.

- You may freely distribute the URL identifying the publication in the public portal. please follow below link for the End User Agreement:

www.umlib.nl/taverne-license

Take down policy

If you believe that this document breaches copyright please contact us at:

repository@maastrichtuniversity.nl

providing details and we will investigate your claim.
}

Copyright and moral rights for the publications made accessible in the public portal are retained by the authors and/or other copyright owners and it is a condition of accessing publications that users recognise and abide by the legal requirements associated with these

- Users may download and print one copy of any publication from the public portal for the purpose of private study or research.

- You may not further distribute the material or use it for any profit-making activity or commercial gain

If the publication is distributed under the terms of Article $25 \mathrm{fa}$ of the Dutch Copyright Act, indicated by the "Taverne" license above, 


\section{FORECASTING FLOWS INTO AND OUT OF}

APPRENTICESHIP TRAINING:

A SCENARIO APPROACH

ROA-RM-1994/2E

Andries de Grip, Henry Berendsen, Lex Borghans, Ron Dekker

Faculty of Economics and Business Administration

University of Limburg

Maastricht, April 1994 


\section{CIP-GEGEVENS KONINKLIJKE BIBLIOTHEEK, DEN HAAG}

\section{Forecasting}

Forecasting flows into and out of apprenticeship training: a scenario approach/Andries de Grip ... [et al.]. - Maastricht : Research Centre for Education and the Labour Market, Faculty of Economics and Business Administration, University of Limburg. - (ROA-RM-1994/2E)

ISBN 90-5321-134-9

Trefw.: stages/bedrijfsopleiding. 


\section{CONTENTS}

ABSTRACT

1. INTRODUCTION 1

2. APPRENTICE INTAKES 4

3. SUPPLY SHORTAGES 9

$\begin{array}{ll}\text { 4. SUCCESS RATES AND OUTFLOWS } & 11\end{array}$

5. SOME LABOUR MARKET ADJUSTMENT SCENARIOS

$\begin{array}{lr}\text { 6. CONCLUSION } & 18\end{array}$

$\begin{array}{lr}\text { REFERENCES } & 19\end{array}$

$\begin{array}{lr}\text { APPENDIX } 1 & 20\end{array}$

$\begin{array}{ll}\text { APPENDIX } 2 & 21\end{array}$

APPENDIX 3 



\section{ABSTRACT}

In this paper a scenario approach is developed as a means of analyzing the policy implications of supply-demand mismatches in the labour market. The paper analyses possible future recruitment problems for apprenticeship training by applying this approach to the future flows of pupils into and out of apprenticeship training in the Netherlands. These scenarios are not formulated, as usually is done, in terms of amendments to the assumptions made, but rather can be seen as the policy targets that should be set to avert the future shortages expected under the basic scenario by focusing recruitment policies on a particular target or target group. Results show that none of the scenarios could, in itself, do more than solve the future shortages expected according to the basic projections to a limited extent. In particular, decreasing the drop-out rates of apprenticeship training appears to be the most promising strategy for several sectors of apprenticeship training, although it would entail quite considerable decreases. 
A good quantitative match between the vocational education system and the labour market is an important requirement if, on the one hand, young people entering the labour market are to have good prospects and, on the other hand, employers' needs for qualified personnel are to be met. But because of the long delays which arise in the education system, this match is often difficult, so that the government considers itself obliged to take steps to improve it. For this purpose, projections of the demand and supply in particular occupational sub-markets may be compiled to serve as indicators of the policy measures which should be taken.

A fundamental objection to such projections, in which demand and supply are usually forecast as if they were independent of each other, is that demand and supply will never in reality develop independently. If the tension between the supply coming from the education system and the demand in the labour market becomes too large, adjustment processes will take place, certainly in the long term. These changes may occur through the working of market forces which tend to reduce the discrepancy between demand and supply, or through government intervention intended, in response to indications that there is a disequilibrium, to reduce friction in the labour market.

In order to gain some understanding of the kinds of adjustments which may arise as an a result of the developments within a segment of the labour market, this paper uses a scenario method which is based on the reversal of the usual scenario approach. A basic scenario is drawn up on the basis of a first projection of demand and supply in the market for apprenticeship places. The basic scenario shows the changes which would occur if there were no adjustments. On this basis, further scenarios are worked out which follow, not from projections based on alternative assumptions, but rather from the changes which are necessary to cancel out the expected discrepancies. Thus forecasts are made of the changes in the supply of workers in a particular occupation (or in this case, of potential workers) which would be required to counter the threat of bottlenecks. These adjustments may either arise through the market mechanism, in the form of recruitment policies etc., or they may be driven by government action. However, in doing so, the limitations to which particular adjustment mechanisms are in practice subject are taken into account. Thus the scenario approach is used as a means of analyzing the policy implications of labour market mismatches for both firms and the government. These 'policy targets' could also be considered as the maximum number of additional apprentices that could be recruited by focusing recruitment policies on one particular target or target group.

The apprenticeship system is an important 'linking pin' between the education system and the labour market at the intermediate level (see e.g. Ryan, 1991). Apprenticeship training plays a particularly crucial role for 'occupational markets', (Marsden and Ryan, 1991). One advantage of apprenticeships is that the vocational training they offer is more closely linked to employment opportunities (Steedman, 1987). However, in the early 80s, the demand in the Netherlands for apprentices was very much less than young people's desire to take up apprenticeship positions. The rationed supply of potential apprentices, combined with the threat of future shortages of 
trained workers, led employers' and employees' organisations, educational authorities and the government to make joint agreements to strengthen the apprenticeship system (see Adviescommissie inzake het Voortgang van het Industriebeleid, 1983). The goal was to double the number of apprenticeships, as compared to the index year of 1982 .

Because this doubling operation achieved its goals, by the late 80 s the reverse situation began gradually to arise: there was not enough interest among young people in taking up apprenticeships. What has particularly caused anxiety in this connection is the decrease in the flow of pupils coming

from Lower Vocational Education (LBO) and Junior General Secondary Education (MAVO). Among the causes of the lower flows coming from these courses, which have traditionally served as preparatory education for the apprenticeship system, are:

- the falling intakes of LBO and MAVO courses as a result of demographic developments;

- the increasing numbers of pupils from these courses who go on to further education within the full-time education system.

Moreover, the purpose of strengthening the apprenticeship system is to increase the numbers of qualified tradesmen to the required level. This depends not only on the flows of apprentices entering the system, but also on the percentage of students that complete the training. Therefore it is also a matter of concern that many students do not complete their apprenticeships.

In this paper the flows into and out of apprenticeship training for the period 1993-2001 are analyzed at the level of the various apprenticeship supervisory boards in the Netherlands. Altogether 24 sectors are distinguished. As noted above, we do not develop scenarios in the usual way by making alternative assumptions with regard to economic growth or the policies followed. Instead, we develop labour market adjustment scenarios which indicate the policy targets that would have to be set in order to avert the future shortages, expected under the basic scenario, in a particular way. The four adjustment scenarios deal with (1) an increase in the participation of women, (2) increasing recruitment of drop-outs from initial full-time education, (3) the replacement of comparable kinds of full-time vocational education with apprenticeships and (4) a decrease in the drop-out rates of apprenticeship training. Strictly speaking the latter scenario does not reduce the shortage of young people entering apprenticeship training. However, since recruitment shortages for apprenticeship training can basically be interpreted as shortages of skilled workers, we have also developed this scenario. In discussing these scenarios, an indication will in each case be given of the extent to which it is, in principle, possible to counter the expected student shortages in that particular way.

This paper proceeds as follows: section 2 will examine changes in the flows of students entering the apprenticeship system, beginning with a brief look at recent developments in the apprenticeship intake, followed by a description of the 'inflow model' that underlies the forecasts of the flows of apprentices. The flows into apprenticeship training are modelled in two steps. In the first step the total inflow of apprentices is modelled, differentiating between the various types of education from which apprentices are recruited. This model also distinguishes 
between the direct flow and an indirect lagged flow out of a 'pool' of potential entrants to apprenticeship training. Using a Random

Coefficients Model which accounts for the reliability of the regression coefficients found, total inflow is differentiated into the 24 apprenticeship training sectors which have been distinguished.

Section 3 will then provide an outline of the policy goals of the apprenticeship supervisory boards ('national organs'), which supervise the apprenticeship schemes for particular industries at a national level, as regards the future flows of apprentices. These objectives are then compared with the forecasts of apprentice intakes. Section 4 focuses on the flows out of the apprenticeship system, beginning with a description of the 'outflow model' which underlies the forecasts of the expected qualified outflow. This also involves an examination of the information on the success rates of the various courses which is obtained by estimating the outflow model. This is followed by an overview of the expected qualified outflow for each apprenticeship sector, if there are no changes in policy.

To supplement the basic scenario of future developments described in sections 2, 3 and 4, section 5 will examine in more detail the possible implications of the four policy scenarios which were listed above. Finally, a number of concluding remarks will be made in section 5 . 


\section{APPRENTICE INTAKES}

By far the most important group entering the apprenticeship system are the qualified school-leavers from Lower Technical Education (LTO). Figure 1 shows that the flow of qualified pupils from LTO diminished markedly in the course of the 80s. In fact it is somewhat surprising that it was possible, from the beginning of the doubling operation in 1982, to achieve a marked increase in the number of students with this educational background entering the apprenticeship system. In the period 1988-1990, the intake of students with an LTO diploma was actually larger than the number of qualified school-leavers leaving LTO. The same phenomena arose for Junior General Secondary Education (MAVO) in 1989. This makes it quite obvious that, to a large extent, recruitment in recent years has been drawing on the existing pool of potential students. It might be possible, if the direct flows into the apprenticeship system remain at the same level, to continue for some years to draw on students who have left full-time eduction one or more years ago, but in the longer term it will not be possible to continue to drain this reservoir to the same extent as in the late 80 's. The growth in the apprentice flows in the 80 s was also in part the result of a substantial increase in the flows of students with educational backgrounds which had not traditionally led on to apprenticeships, such as Senior General Secondary Education (HAVO) and drop-outs from Intermediate Vocational Education (MBO). However the growth in this intake category also stagnated in the late 80 s.

Figure 1. Changes in the certificated outflow from LTO, compared to the intake of new apprentices with LTO certificates

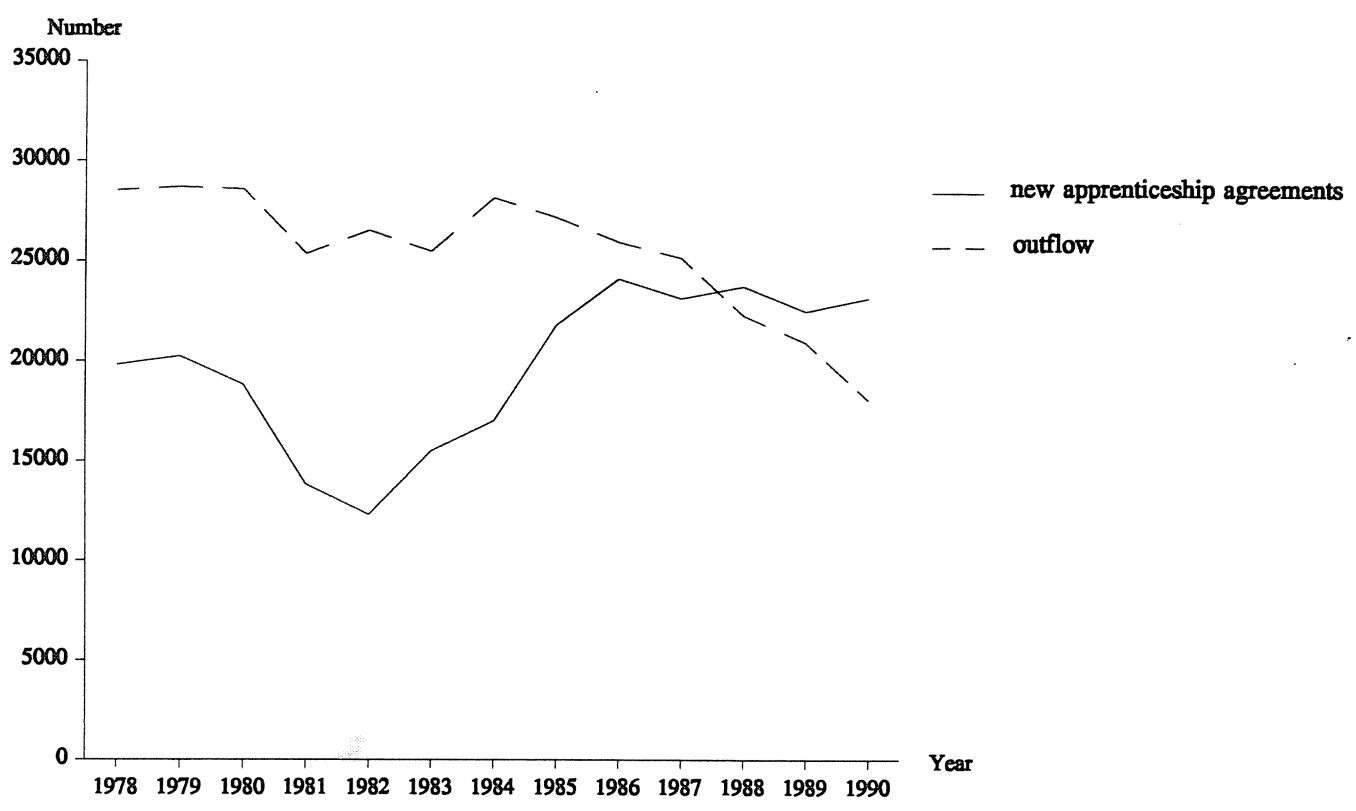

Source: CBS/Ministry of Education and Science/CORO/ROA 
Forecasts of the expected intakes of the various types of apprenticeships for the years 1993-2001 have been compiled on the basis of, first, a model of the total intake from each type of previous education, and second, a simple distribution model to divide these flows among the various apprenticeship boards. In designing the model of the total flows of apprentices, it was assumed that, in addition to the direct flows from the various educational backgrounds, it is also possible to recruit from the pool of potential apprentices built up during the previous five years:

$S_{k}^{t}=\sum_{i=0}^{5} U_{k}^{t-i}-\sum_{i=1}^{5} N_{k}^{t-i}$

in which:

$S_{k}^{t} \quad=$ the number of students with educational background $k$ who, in year $t$, were available to enter the apprenticeship system;

$O_{k}^{t} \quad=\quad$ the outflow in year $t$ from previous education type $k$;

$N_{k}^{t}=\quad=$ the number of students with educational background $k$ who, in year $t$, enter the apprenticeship system.

Thus all those who have completed a preparatory educational course in the current year or one of the five previous years can in principle, according to this model, enter the apprenticeship system, unless they have already entered it. The assumption is that the intake of the apprenticeship system follows a trend in relation to the total number of potential apprentices. Nevertheless, the fact that the start of the doubling operation in 1982 might have led to a break in the trend has been taken into account.

The model to be estimated was therefore specified as follows:

$\frac{N_{k}^{t}}{S_{k}^{t}}=c_{k}+d_{k}^{1} t^{\text {pre82 }}+d_{k}^{2} t^{\text {past82 }}$

where:

$t^{\text {pre82 }}=$ trend variable for changes in flows into the apprenticeship system before 1982 (1982 =0);

$t^{\text {past82 }}=$ trend variable for changes in the flows into the apprenticeship system after 1982 $(1982=0)$;

$c_{k}, d_{k}^{1}$ and $d_{k}^{2}$ are parameters; and $c_{k} \geq 0$.

Table 1 provides an overview of the results of the estimation. The high corrected R2 indicates that the model can provide a good explanation of changes in the total flows into the apprenticeship system from each type of previous education. For a number of preparatory courses there is a significant autocorrelation in the error term. For those with an LTO diploma, this is due to the extremely high intakes in the last years covered by the data. However, after correcting the estimates by incorporating an $A R(1)$ error term the remaining error terms are not significantly autocorrelated anymore. This correction proved to have little effect on the model parameters. For that reason the uncorrected estimates have been used to avoid difficulties with the prediction due to the interaction of the $A R(1)$ error and the stock of students available to 
enter the apprenticeship system. The table shows that there was a significant reduction in the intake from a number of preparatory courses up to 1982. After the doubling operation in 1982, there was a significant increase in the intake from all types of previous education which have been distinguished here. This shows the success of the operation. The largest growth was for students from LTO, which was already the group which provided the largest number of new apprentices. But since the interest in LTO itself has in recent years declined markedly, this relative increase in the interest of LTO students in taking up apprenticeships will in absolute terms make ever less difference, and the effect of the doubling operation will therefore gradually ebb away.

Table 1. Estimation results of the total apprentice intake, by kinds of previous education, 1978-1990

\begin{tabular}{|c|c|c|c|c|c|}
\hline & constant & $\begin{array}{l}\text { trend } \\
\text { before } \\
1982\end{array}$ & $\begin{array}{l}\text { trend } \\
\text { after } \\
1982\end{array}$ & $\bar{R}^{2}$ & D.W. \\
\hline LTOc & $\begin{array}{l}0.13416 \\
(4.25)\end{array}$ & $\begin{array}{l}-0.05059 \\
(3.32)\end{array}$ & $\begin{array}{l}0.05156 \\
(5.64)\end{array}$ & 0.96 & $0.67^{\circ}$ \\
\hline LHNOC & $\begin{array}{l}0.04565 \\
(14.73)\end{array}$ & $\begin{array}{l}- \\
-\end{array}$ & $\begin{array}{l}0.01218 \\
(10.98)\end{array}$ & 0.98 & 1.55 \\
\hline LMOc & $\begin{array}{l}0.01056 \\
(8.85)\end{array}$ & - & $\begin{array}{l}0.00315 \\
(8.75)\end{array}$ & 0.97 & 1.02 \\
\hline LEAO $c$ & $\begin{array}{l}0.01358 \\
(4.12)\end{array}$ & - & $\begin{array}{l}0.00688 \\
(6.59)\end{array}$ & 0.92 & $0.55^{\circ}$ \\
\hline MAVAc & $\begin{array}{l}0.02447 \\
(5.11)\end{array}$ & - & $\begin{array}{l}0.02586 \\
(8.57)\end{array}$ & 0.93 & $0.53^{\circ}$ \\
\hline LTOu & $\begin{array}{l}0.02113 \\
(6.65)\end{array}$ & $\begin{array}{l}-0.01403 \\
(9.08)\end{array}$ & $\begin{array}{l}0.00429 \\
(5.09)\end{array}$ & 0.98 & 1.65 \\
\hline OTHER $u$ & $\begin{array}{l}0.01031 \\
(4.908)\end{array}$ & $\begin{array}{l}-0.00456 \\
(4.96)\end{array}$ & $\begin{array}{l}0.00359 \\
(5.85)\end{array}$ & 0.97 & 1.80 \\
\hline
\end{tabular}

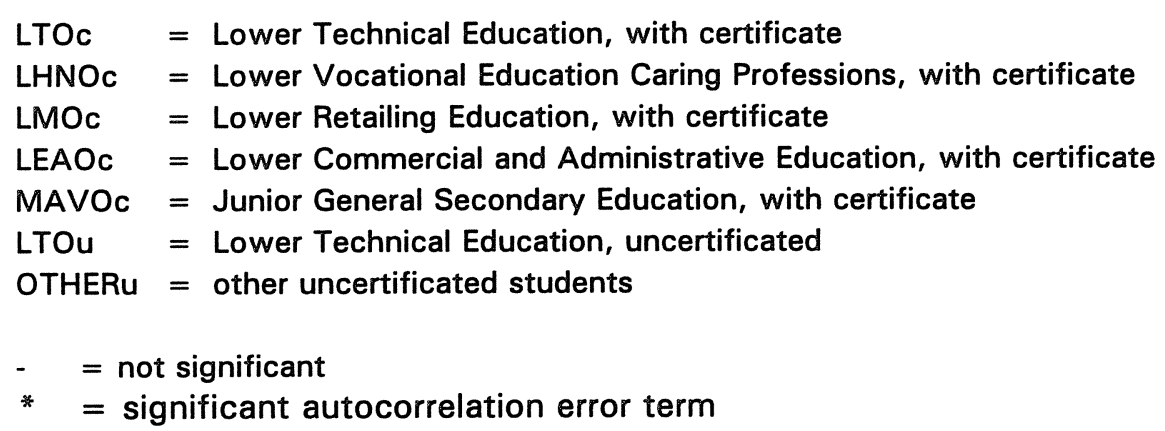

After designing the model of the intake from each type of previous education, these intakes are divided over the various apprenticeship sectors using a distribution model. The use of a distribution model ensures that, for every type of previous education, the total magnitude of the forecast intake is consistent with the magnitude of the intake which was forecast in the first step. In the form of an equation: 


$$
\sum_{k} N_{k}^{t}=\sum_{k} \sum_{l} N_{k l}^{t}=\sum_{l} N_{l}^{t}
$$

where:

$$
\begin{aligned}
N_{k}^{t}= & \text { the number of students with educational background } k \text { who, in year } t \text {, enter the } \\
& \text { apprenticeship system; } \\
N_{k l}^{t} \quad= & \text { the number of students with educational background } k \text { who, in year } t \text {, enter an } \\
& \text { apprenticeship scheme supervised by apprenticeship board } l ; \\
N_{l}^{t} \quad= & \text { the number of students who, in year } t \text {, enter an apprenticeship scheme supervised } \\
& \text { by apprenticeship board } l .
\end{aligned}
$$

Let $f_{k l}^{t}=N_{k l}^{t} / N_{k}^{t}$ be the fraction of the intake with educational background $k$ who enter an apprenticeship scheme supervised by apprenticeship board $l$. The sum of these fractions for all of the apprenticeship boards for any one type of previous education will be 1 :

$$
\sum_{l} f_{k l}=1
$$

In the distribution model the changes in these fractions are estimated with the aid of a Random Coefficients Model (R C model). This RC model, in contrast to other estimation methods, makes allowance for the reliability of the connections between endogenous and explanatory variables which may be found. ${ }^{1}$

Finally, the total inflow for each apprenticeship sector is obtained by multiplying the estimated fractions from the distribution model by the estimated intake for each type of previous education, and aggregating the result for the various types of apprenticeship falling under each apprenticeship board:

$$
\hat{N}_{l}^{t}=\sum_{k} \hat{f}_{k l} \cdot \hat{N}_{k}^{t}
$$

The forecasts of the flows of students leaving the various kinds of previous education are derived from the Reference Estimates 1992 of the Ministry of Education and Science.

Figure 2 shows that, like the expected annual outflow of students leaving their initial full-time education with LTO certificates, the expected intake of students with LTO certificates entering the various types of apprenticeship course will fall sharply in the early 90s. Naturally this has a considerable effect on the intakes of the various types of apprenticeship, which are largely dependent on LTO recruits. Moreover the figure shows that recruiting students from the pool of past LTO graduates will not be possible after 1993, since the pool has been exhausted in recent years. As a result of the depletion of this pool, the total intake of students with LTO certificates

1. For a technical explanation see Borghans and Heijke (1994). For the purposes of this paper it is not necessary to give a complete overview of the large number of fractions which were estimated. 
in the middle of the 90s will again fall below the annual outflow.

Appendix 1 shows that, on the whole, the apprentice intake in the medium term (1997) is expected to fall sharply as compared with the intake in 1991, with a decrease in the intake from more than 45,000 students in 1991 to less than 37,000 students in 1997 (a decrease of some $18 \%)$. The most striking decreases are in the apprentice intakes for construction workers for civil engineering $(-35 \%)$, bakery workers $(-34 \%)$, training for the commercial and administrative occupations $(-33 \%)$ and tradesman's training for electricians $(-32 \%)$. In contrast, an increase in the intake is expected for only three sectors: technical trades in health care $(+35 \%)$, the textile industry $(+7 \%)$ and apprenticeships for the wholesale and retail sector $(+2 \%)$.

Figure 2. Forecasts of the certificated flows from LTO education compared to forecast intakes of certificated LTO students entering the apprenticeship system, 1991-2001

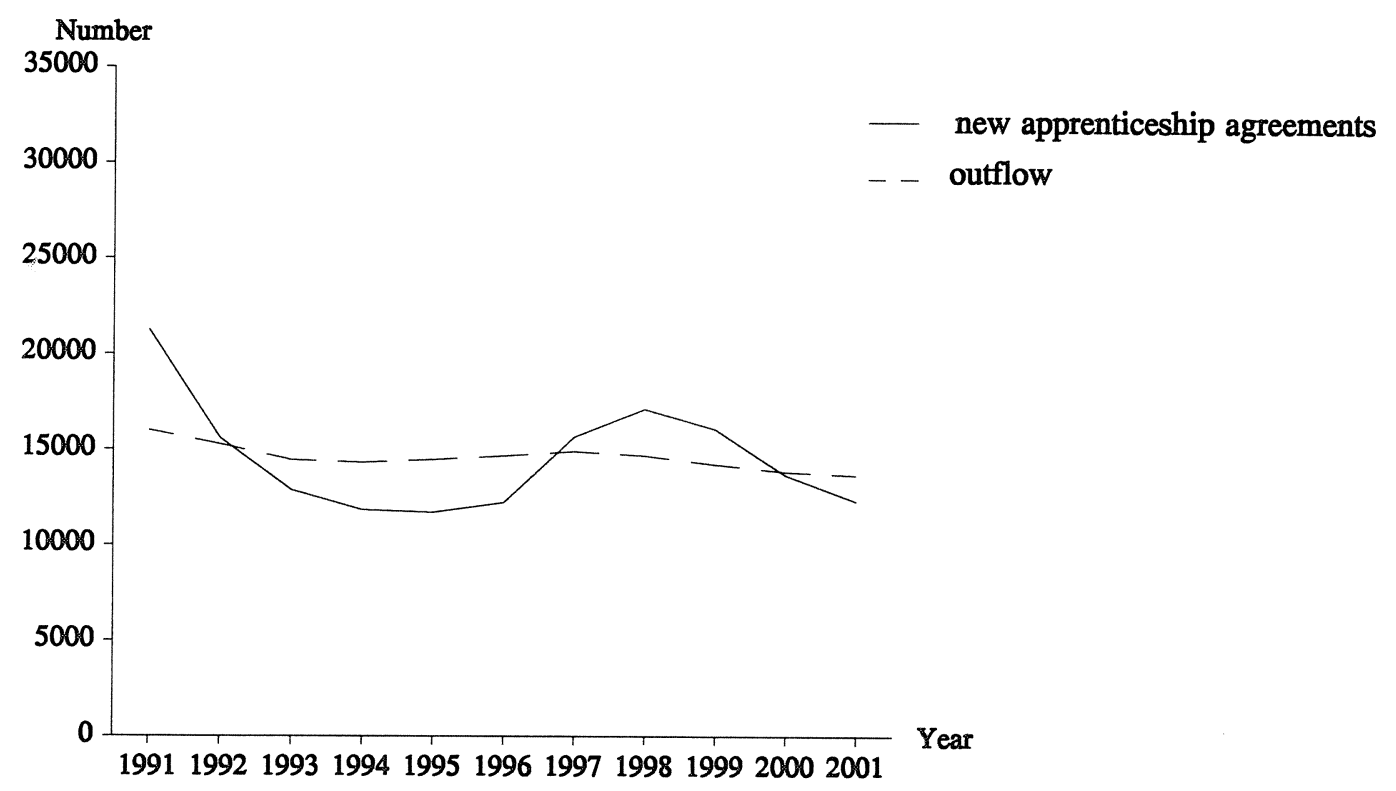

* The figure for 1991 is the actual outcome, not a forecast

Source: Ministry of Education and Science/ROA

According to the basic scenario, a further decrease in the apprentice intake of almost $10 \%$ is to be expected for the period 1997-2001. Once again the decline is expected to be greatest among the civil engineering construction workers $(-25 \%)$, bakery workers $(-25 \%)$ and electricians $(-24 \%)$. On the other hand, in this period an increase is expected in the intakes of six apprenticeship supervisory boards. In addition to the sectors which had already seen their intakes rise in the period 1991-1997, a small increase in apprentice intakes is now also expected in the ready-made clothing industry $(+6 \%)$, hairdressing $(+4 \%)$ and nursing and care-giving occupations $(+3 \%)$. 


\section{SUPPLY SHORTAGES}

As was said above, in order to discover the extent to which the various apprenticeship supervisory boards will be able to meet their future needs for recruits for the various types of apprenticeships, the forecasts of the expected apprentice intakes under the basic scenario were compared with the policy goals of the apprenticeship boards, derived from the Apprenticeship Subsidy Scheme (BVL) target figures.

For the majority of the apprenticeship supervisory boards, intake requirements were assumed to be constant at the level of the planned intake for 1992. The wholesale and retail sector, road transport and the textile industry are exceptions to this rule. For the wholesale and retail sector, it was assumed that intake requirements would increase by $5 \%$ annually until 1997 , and would then remain constant at the 1997 level. For the two other apprenticeship boards, an annual increase in the intake requirements of $10 \%$, up to 1997, was assumed. After 1997 the intake requirements are expected to stabilize.

Table 2 shows that a total shortage of more than 12,000 apprentices is expected for 1997, equivalent to some $25 \%$ of the planned apprentice intake. The greatest shortages are expected in the sectors with the highest planned increases in their intakes: road transport (74\% shortfall) and the textile industry (61\% shortfall). Other sectors which are expected to face large relative apprentice shortages are the baking industry (40\% shortfall), the building trades (35\% shortfall), the administrative occupations ( $34 \%$ shortfall) and construction workers for civil engineering (34\% shortfall).

According to expectations, by 1997 only a few sectors within the apprenticeship system will not (yet) be facing shortages in their apprentice intakes: hairdressing, technical trades in health care and the vehicle and bicycle trade. The ready-made clothing industry and the nursing and care-giving occupations will also suffer little or no shortage of apprentices. For hairdressing, in fact, a relatively large excess in supply is expected.

In the long term it is expected that the total shortage of apprentices will increase to almost 16,000 in the year 2001, or 32\% of the planned intake. In 2001 the same apprenticeship boards, in general, will face relatively large shortfalls as in 1997, but with marked increases in the shortfall expected for electricians (from $28 \%$ to $45 \%$ ), construction workers for civil engineering (from $34 \%$ to $50 \%$ ) and bakery workers (from $40 \%$ to $55 \%$ ). The over-supply in the vehicle and bicycle trade in 1997 will turn into a shortfall in 2001. 
$-10-$

Table 2. Expected over-supply and shortages for new apprentices under the basic scenario, 1997 and 2001, (in absolute figures and as percentages of the planned intake)

\begin{tabular}{|c|c|c|c|c|}
\hline \multirow{2}{*}{$\begin{array}{l}\text { Supervisory } \\
\text { Board }\end{array}$} & \multicolumn{2}{|c|}{1997} & \multicolumn{2}{|c|}{2001} \\
\hline & number & $\%$ & number & $\%$ \\
\hline Wholesale and retail & $-1,608$ & -29 & $-1,149$ & -21 \\
\hline Administration & -746 & -34 & -948 & -43 \\
\hline Road Transport & $-2,589$ & -74 & $-2,738$ & -79 \\
\hline Metals Industries & $-1,141$ & -25 & $-1,787$ & -39 \\
\hline Building trades & $-1,389$ & -35 & $-1,833$ & -46 \\
\hline Painters & -402 & -27 & -587 & -40 \\
\hline Vehicle and Bicycle trade & 92 & 3 & -293 & -10 \\
\hline Confectionary & -78 & -18 & -85 & -20 \\
\hline Electricians & $-1,386$ & -28 & $-2,269$ & -45 \\
\hline Health Care, technical trades & 46 & 10 & 132 & 29 \\
\hline Printing sector & -439 & -29 & -583 & -39 \\
\hline Ready-made clothing & -2 & -1 & 21 & 5 \\
\hline Hotel and catering & -675 & -23 & -881 & -30 \\
\hline Processing industry & -146 & -10 & -298 & -21 \\
\hline Nursing and care-giving & -38 & -2 & 23 & 1 \\
\hline Civil engineering construction & -371 & -34 & -553 & -50 \\
\hline Coach builders and panel-beaters & -163 & -16 & -200 & -20 \\
\hline Textile industry & -300 & -61 & -295 & -60 \\
\hline Carpenters and cabinet-makers & -365 & -30 & -529 & -44 \\
\hline Bakery workers & -303 & -40 & -417 & -55 \\
\hline Hairdressing & 701 & 30 & 827 & 36 \\
\hline Butchers & -337 & -23 & -363 & -25 \\
\hline Installation engineers & -705 & -29 & -958 & -40 \\
\hline Total & $-12,411$ & -25 & $-15,833$ & -32 \\
\hline
\end{tabular}




\section{SUCCESS RATES AND OUTFLOWS}

Since intake targets in the apprenticeship system are not established for their own sake, but rather as instruments to ensure that future needs for certificated tradesmen can be met, it is important to relate the intake to the flows of qualified students leaving the apprenticeship system. We therefore use the internal success rates of the apprenticeship courses. If the intake falls below requirements, this could be compensated for by an increase in apprentices' success rate. In order to determine the success rates, for each apprenticeship supervisory board the annual outflow from the various types of apprenticeships was compared to the intake of new apprentices in previous years. In order to determine these success rates, the annual outflow of those who have completed apprenticeships of the various types supervised by each national apprenticeship board is compared to the intakes of students in the previous years.

Because the nominal training period for the various types of apprenticeships is two or three years, it is in principle possible to distinguish between five possibilities: students gain their certificate after either two or three years, or they leave the system without a certificate after one, two or three years. Any particular intake cohort can thus be divided into the fractions $P_{s u c}^{2}$ and $P_{s u c}^{3}$ for those who have succeeded after two and three years, respectively, and $P_{d r o p}^{1}, P_{d r o p}^{2}$ and $P_{d r o p}^{3}$ for the dropouts after one, two and three years, respectively. These five fractions must, by definition, add up to 1 . The model to be estimated then reads as follows:

$$
\begin{aligned}
& G_{l}^{t}=P_{s u c, l}^{2} N^{t-2}+P_{s u c, l}^{3} N^{t-3}+\epsilon_{s u c, l}^{t} \\
& U_{l}^{t}=P_{d r o p, l}^{1} N^{t-1}+P_{d r o p, l}^{2} N^{t-2}+P_{d r o p, l}^{3} N^{t-3}+\epsilon_{d r o p, l}^{t}
\end{aligned}
$$

where:

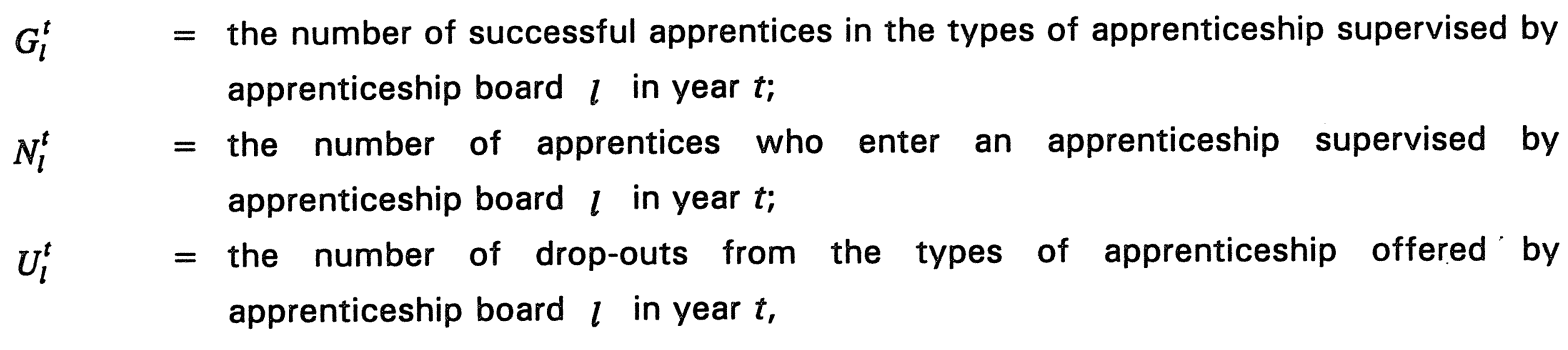

with the restriction:

$$
P_{s u c, l}^{2}+P_{s u c, l}^{3}+P_{d r o p, l}^{1}+P_{d r o p, l}^{2}+P_{d r o p, l}^{3}=1
$$

This parameter restriction results in the following specification:

$$
G_{l}^{t}=P_{s u c, l}^{2} N_{l}^{t-2}+P_{s u c, l}^{3} N_{l}^{t-3}+\epsilon_{s u c, l}^{t}
$$




$$
U_{l}^{t}=P_{d r o p, l}^{1} N_{l}^{t-1}+P_{d r o p, l}^{2} N_{l}^{t-2}+\left(1-P_{s u c, l}^{2}-P_{s u c, l}^{3}-P_{d r o p, l}^{1}-P_{d r o p, l}^{2}\right) N_{l}^{t-3}+\epsilon_{d r o p, l}^{t}
$$

Because of the relationship between the parameters of the two equations and the possible connection between the error terms $\epsilon_{\text {suc,l }}^{t}$ and $\epsilon_{d r o p, l}^{t}$, this model is estimated using the Seemingly Unrelated Regressions Model (SUR). Since this estimation method does not guarantee that the parameters lie between 0 and 1 , it was necessary to include this restriction for a number of apprenticeship boards. This was done in successive steps, by selecting, from all of the parameters which lay outside the boundary value, the one which had the highest $t$-value in the estimation. This parameter is then set equal to the boundary value, and the model is reestimated. This procedure is repeated until all the parameters fall within the boundary values.

In fact only the first four outflow figures are estimated, since the fifth fraction can be derived from these estimates:

$$
P_{d r o p, l}^{3}=1-P_{s u c, l}^{2}-P_{s u c, l}^{3}-P_{d r o p, l}^{1}-P_{d r o p, l}^{2}
$$

The equations for the success rate and the drop-out rate are as follows:

$$
\begin{aligned}
& \operatorname{rend}_{l}=P_{s u c, l}^{2}+P_{s u c, l}^{3} \\
& \text { drop-out } t_{l}=1-\text { rend }_{l}
\end{aligned}
$$

where:

$$
\begin{aligned}
\text { rend }_{l}= & \text { the success rate of the apprenticeships supervised by apprenticeship } \\
& \text { board } l ; \\
\text { drop-out } t_{l}= & \text { the drop-out rate of the types of apprenticeships supervised by apprenticeship } \\
& \text { board } l .
\end{aligned}
$$

Finally, the fraction of students who drop out within the first year is defined as:

$$
f r_{d r o p, l}^{1}=\frac{P_{d r o p, l}^{1}}{P_{d r o p, l}^{1}+P_{d r o p, l}^{2}+P_{d r o p, l}^{3}}
$$

where:

$$
\begin{aligned}
f r_{d r o p, l}^{1}= & \text { the fraction of students in the types of apprenticeships supervised by } \\
& \text { apprenticeship board } l \text { who drop out within the first year. }
\end{aligned}
$$

Appendix 2 gives an overview of the estimation results, focusing on the success rate, the dropout rate, and the proportion of the students who drop out within the first year. ${ }^{2}$ Because the restrictions have little influence on the estimations of success rates, the various ratios in this

2. A complete listing of the estimated outflow fractions can be found in De Grip c.s. (1993), table 3.2. 
table are based on the unrestricted estimates. This makes it possible to calculate the standard errors for the success rates and the drop-out rates on the basis of the covariance matrix of the estimated parameters. Because the relation between the first year drop-out fraction and the parameters of the model is non-linear, no estimation was made of the standard errors.

Figure 3 shows that, in the period 1980-1991, the success rates of the types of apprenticeships in the various sectors lay between $38 \%$ and $68 \%$. The lowest success rate was for electricians $(38 \%)$, with wholesale and retail apprenticeships $(40 \%)$, administrative occupations $(43 \%)$ and technical trades in health care (43\%) also having very low success rates. The highest success rate was in the printing sector $(68 \%)$, with the nursing and care-giving occupations $(67 \%)$, road transport $(65 \%)$ and bakery workers $(65 \%)$ also having relatively high success rates in their apprenticeship programmes.

Figure 3. Success rate per supervisory board

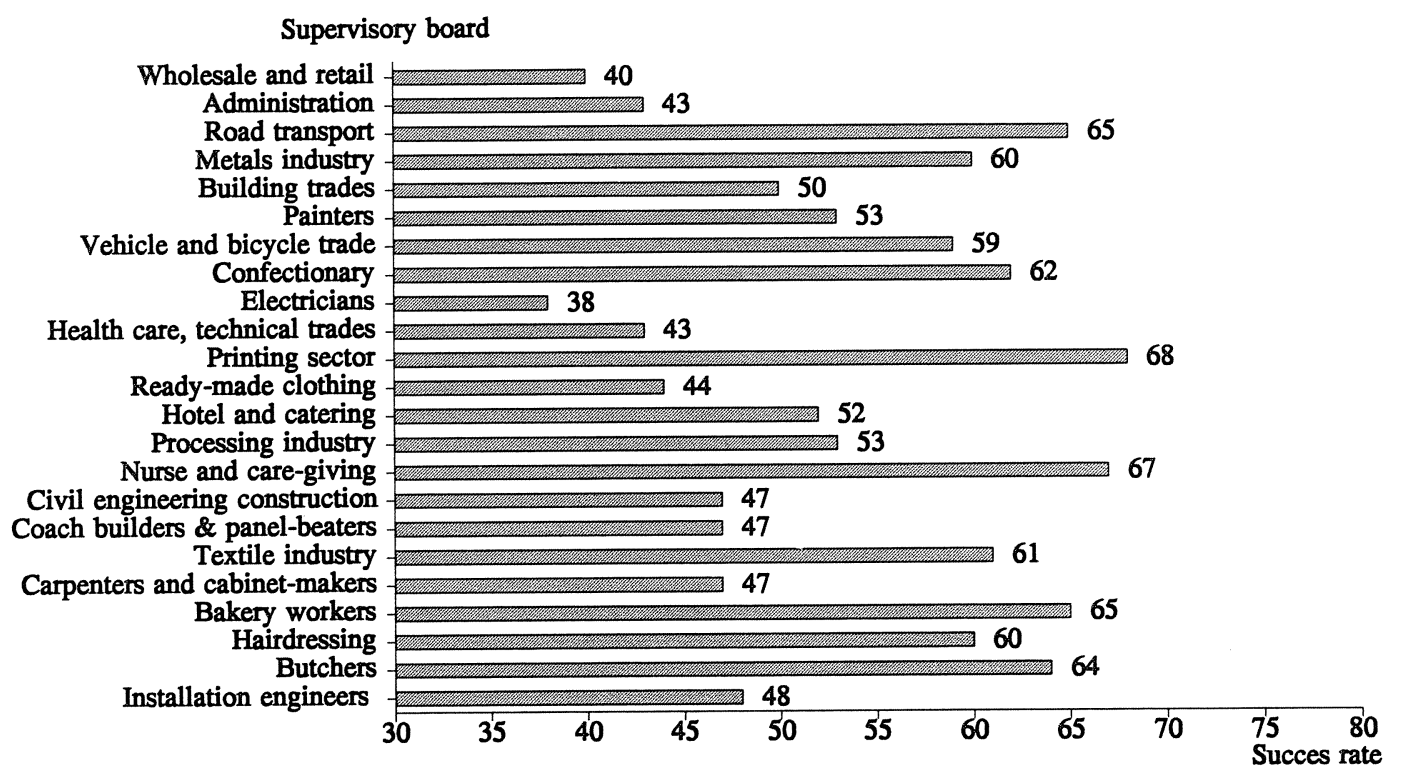

Outflow

On the basis of the estimations of the success rates of the various types of apprenticeships in each sector of the apprenticeship system, the forecasts of apprentice intakes can be translated into forecasts of the certificated outflow for each sector (see appendix 3). In the basic scenario the total certificated outflow from all types of apprenticeships in 1997 is expected to be $28 \%$ lower than the total outflow in 1991. This fall in the certificated outflow is steeper than the drop in the intake because 1997 will see a slight recovery in the sharp drop in the intake. This recovery is not at that time visible in the outflow, because of the inevitable delay between inflow and outflow. An increase in the outflow is expected for only three sectors: the textile 
industry $(+60 \%)$, technical trades in health care $(+51 \%)$ and bakery workers $(+5 \%)$. A large decrease in the certificated outflow is expected mainly for bakery workers $(-53 \%)$, painters $(-45 \%)$, the building trades $(-41 \%)$ and the vehicle and bicycle trade $(-40 \%)$.

In the period 1997-2001, in comparison with the decline in the outflow in 1997, a clear recovery is expected in the certificated outflow from apprenticeship schemes. Nevertheless the total outflow in 2001 is still expected to be around $12 \%$ lower than the certificated outflow in 1991: a decrease of more then 2,500 .

The improvement in the certificated outflow is across the board, with the exception of the administrative occupations, for which the outflow will remain at the 1997 level. Large increases in the outflow are expected mainly in the processing industry $(+40 \%)$, which will mean that the certificated outflow for this apprenticeship board in 2001 is expected to be appreciably higher than in the year 1991. Road transport $(+37 \%)$, the vehicle and bicycle trade $(+35 \%)$ and the confectionery trade $(+32 \%)$ are also expected to see significant increases in the outflow during the period 1997-2001. For these apprenticeship boards it is a case of a clear recovery after the marked decrease in the outflow in the first half of the 90s. For the technical trades in health care, a roughly similar increase in the certificated outflow is expected $(+35 \%)$, which will mean that the outflow for this national apprenticeship board in 2001 will be more than double the outflow in 1991, although in absolute terms they remain relatively small. 


\section{SOME LABOUR MARKET ADJUSTMENT SCENARIOS}

Four adjustment scenarios have been developed to examine the extent to which the apprentice shortages which are expected under the basic scenario could be averted. These adjustment or 'policy' scenarios give an idea of the policy goals which would have to be set if the intake and outflow shortages which would be expected according to the basic scenario are to be averted using a particular recruitment policy or other policy line. For each sector we examined which concrete policy goals would have to be set in a particular area in order to avert, so far as possible, the expected shortages of apprentices. These could also be regarded as the maximum market adjustments which should be achievable on the basis of the impulses generated in the market to restore the equilibrium between demand and supply. However in this respect the approach which has been used is only partial, in that an indication is given of the extent to which the shortfall anticipated under the basic scenario could be countered by achieving a single policy goal. In practice a combination of measures would normally be put in place. In principle a corresponding combination could then be made from the partial approaches which have been used.

\section{Increasing the intakes of women}

The first possible way to increase the intake of the apprenticeship system is by ensuring that more female apprentices enter the system than at present. In order to make this policy scenario reasonably realistic, it was assumed that the maximum achievable policy goal would be if the percentage of women with a particular type of previous education who took up apprenticeships in a particular sector was the same as the percentage of men with the same previous education doing so.

The forecast results for this scenario show that, for 13 of the 20 sectors which face shortages of apprentices, attracting more women should make it possible to avert these shortages in 1997, but by 2001 this policy line would be sufficient for only 4 of the 20 sectors. Of the sectors for which the basic scenario indicated relatively large expected shortages, attracting more women is only sufficient in the medium term for civil engineering construction workers and for the administrative occupations. However in the longer term, increasing the intake of women is not sufficient to entirely prevent the expected shortages for any of these sectors. Nevertheless, attracting more female apprentices offers several of the apprenticeship supervisory boards which face relatively high shortages of apprentices good possibilities to considerably reduce the expected shortfall. In addition to the administrative occupations and construction workers in civil engineering, this applies especially to painters, the textile industry and bakery workers. However, considerable policy efforts would generally be required to achieve this. The overall proportion of apprentices in the various courses who are female would have to increase by 18 percentage points in 1997, to $44 \%$ of the total intake. In 2001 the share of the women in the total intake would have to be as high as $46 \%$. 
The second policy scenario relates to increasing the intake of what could be called the hard core of premature school-leavers: i.e., the drop-outs who leave their initial full-time education without an LBO or MAVO certificate. In order to get the most realistic picture possible of the opportunities available to the various apprenticeship supervisory boards of attracting more drop-outs of initial full- time education, it was assumed that, if more apprentices with a given educational background entered the apprenticeship system, this increased intake would be spread over the various sectors in accordance with the spread of the existing intake of drop-outs.

From the forecast results for this scenario it can be seen that, for 10 of the 20 apprenticeship supervisory boards for which a shortage of apprentices is expected in the basic scenario, this shortfall could in principle be prevented in 1997 by increasing the intake of students without any qualifications. In 2001 this would be effective for only 6 of the 20 apprenticeship boards. However this option would mean that, for many apprenticeship boards, almost the whole potential target group would have to choose a training course in the apprenticeship system, and for the other apprenticeship supervisory boards a very large increase in the unqualified intake would generally also be required. For the apprenticeship boards for which relatively large supply shortages are expected (i.e., especially the administrative occupations, the building trades, civil engineering construction workers, the textile industry and bakery workers), increasing the unqualified intake offers the possibility of reducing the future shortage of apprentices. In addition to uncertificated school-leavers from LBO and MAVO education, many more unqualified students from Senior General Secondary Education and University Preparatory Education would also have to be recruited.

\section{Dual format for Shorter Intermediate Vocational Education}

A third possibility to increase the intake of the apprenticeship system is to transform Shorter Intermediate Vocational Education (KMBO) into a dual education system. Such a transformation would be in accordance with the desire to improve the match between the education system and trade and industry by increasing the importance of dual education. However in fact this amounts to no more than diverting supply from the KMBO to the apprenticeship system. The resulting reductions in the KMBO system would mean that the ultimate supply of qualified workers would not in fact increase, assuming that the drop-out rates would not change if these courses were changed to an apprenticeship format.

In order to get the most realistic possible impression of the extent to which this policy scenario could prevent future shortages in the apprenticeship system, it was assumed that a sector can only draw on the reservoir of reasonably similar training courses in the KMBO. This means that this scenario is not relevant for the sectors for which there is no parallel training course within the $\mathrm{KMBO}$, i.e., for road transport, civil engineering, construction workers, coach building and panel beating, the textile industry and butchers. 
The forecast results from this policy scenario show that transforming the parallel KMBO courses into apprenticeships offers 8 of the 20 sectors in which a shortage of apprentices is expected in 1997 a way to prevent these shortages. In 2001 it would be sufficient for only 5 of the 20 sectors: wholesale and retail apprenticeships, the administrative occupations, the vehicle and bicycle trade, the confectionary trade and the processing industry. Of the sectors in which the largest shortages of apprentices are expected, such a transformation of the KMBO only offers the administrative occupations a possibly way of preventing future shortages of apprentices. For the building trades, in contrast, there would only be a minimal reduction in the expected shortfall, because the parallel training course in the KMBO system has very few students. For bakery workers, this policy scenario could also lead to a less serious future apprentice shortage, although it should be remembered that this sector is in competition with the confectionary trade for the same potential apprentice intake. For the other sectors for which a relatively large apprentice shortage is expected (road transport, the textile industry and civil engineering construction workers), this alternative scenario does not offer any solution, because there is no reasonably similar training course within the KMBO system.

\section{Increase the success rate}

The last policy scenario which was examined focused on the extent to which increasing the success rate of apprenticeship courses could restore the equilibrium in the future ratios between demand and supply within the apprenticeship system. This scenario shows the extent to which the success rate would have to be increased in order to enable the intake targets to the point that the predicted supply would no longer be a bottleneck in meeting the future demand for trained workers. The results for this scenario show that, for some 16 of the 20 sectors for which inadequate supplies of apprentices are expected in 1997, increasing the success rate could avert these shortages. In 2001 this would still be true for 15 of the apprenticeship supervisory boards. However, for a number of sectors this would mean that the success rate would have to be improbably high. For the apprenticeship system as a whole, the success rate of the apprenticeship courses in 1997 would have to be $70 \%$. This implies an increase of some 17 percentage points as compared with the average success rate for apprentices in the period 1986-1991. In 2001 the average success rate would have to be $80 \%$ to overcome the expected shortages, by this policy line. Of the sectors for which the largest shortages of apprentices are expected, only the civil engineering construction workers, the building trades and the administrative occupations could avoid the expected shortfall in both 1997 and 2001 under this policy scenario, providing a considerable increase in their success rates could be achieved. 


\section{CONCLUSION}

For each of the various policy scenarios which were elaborated in this study, a partial approach was employed, examining in each case the extent to which the shortages expected under the basic scenario could be prevented by that particular policy line. Thus this approach does not consider the developments in demand and supply as if they were independent, but rather show what kinds of adjustments are necessary to keep the market in reasonable equilibrium. These adjustments could come about through market forces, in the form of recruitment policies etc., or through government (and/or supervisory boards) intervention. These scenarios can therefore be seen as the policy targets that should be set in order to prevent the expected future shortages seen in the basic scenario by focusing recruitment policies on a particular target or target group. For the administrative occupations, the application of the policy line in one of the four scenarios on its own would, in most cases, be sufficient to avert the expected shortages in 1997. Only an increase in the intake of drop-outs of full-time initial education to the courses would, even for this sector, not be sufficient to meet the expected apprentice shortage. Transforming KMBO courses into dual education courses or increasing the success rate of the apprenticeship courses would, for the administrative occupations, also be sufficiently effective to prevent the expected shortages in the year 2001.

For civil engineering construction workers, increasing the intake of women or the success rate could bring demand and supply into equilibrium, although increasing the intake of women would only be a solution for this sector for 1997. In principle, increasing the success rate could also avert the expected future shortages of apprentices in civil engineering construction, but this requires an improbably low drop-out rates.

The overall conclusion is that the expected shortages, especially in those sectors for which relatively large shortages of apprentices are expected, can only be adequately countered if policy efforts are made in several areas at once. In particular, achieving a substantial increase in the success rate of their apprenticeship schemes might be expected to prove an effective means for many apprenticeship boards to prevent the supply shortages which would be expected on the basis of the basic scenario. However the other adjustment scenarios also offer quite credible opportunities of considerably reducing the expected shortages of apprentices. A policy focused on increasing the intake of women could have an even greater effect if an effort was made to attract more women with an educational background other than the traditional types of previous education from which that sector recruits its apprentices. 


\section{REFERENCES}

Adviescommissie inzake de Voortgang van het Industriebeleid, (1983), Vers/ag van werkzaamheden 2, 's-Gravenhage.

Borghans L., H. Heijke (1994), Een random-coëfficiënten-model voor het voorspellen van de beroepenstructuur van bedrijfstakken, ROA-W-1994/1, Maastricht.

Grip, A. de, H. Berendsen, L. Borghans, R.J.P. Dekker (1993), Toekomstverkenning leerlingwezen, ROA-R-1993/4, Maastricht, 1993.

Marsden, D., P. Ryan (1991) Initial Training, Labour Market Structure and Public Policy: Intermediate Skills in British and German Industry, in P. Ryan (ed.) International Comparisons of Vocational Education and Training for Intermediate Skills, Falmer Press, London.

Ryan, P. (1991) International Comparisons of Vocational Education and Trading for Intermediate Skills, Falmer Press, London.

Steedman, H. (1987), Vocational Training in France and Britain: Office Work, National Institute Economic Review, May 1987, pp. 58-70. 
Appendix 1. Expected apprentice intakes per supervisory board under the basic scenario, 1997 and 2001, (in absolute figures)

\begin{tabular}{|c|c|c|c|}
\hline $\begin{array}{l}\text { Supervisory } \\
\text { Board }\end{array}$ & $1991^{*}$ & 1997 & 2001 \\
\hline Wholesale and retail & 3,814 & 3,880 & 4,339 \\
\hline Administration & 2,162 & 1,459 & 1,257 \\
\hline Road Transport & 1,144 & 898 & 749 \\
\hline Metals Industries & 4,580 & 3,419 & 2,773 \\
\hline Building trades & 3,403 & 2,611 & 2,167 \\
\hline Painters & 1,458 & 1,078 & 893 \\
\hline Vehicle and Bicycle trade & 3,362 & 2,892 & 2,507 \\
\hline Confectionary & 382 & 347 & 340 \\
\hline Electricians & 5,315 & 3,614 & 2,731 \\
\hline Health Care, technical trades & 371 & 504 & 590 \\
\hline Printing sector & 1,307 & 1,061 & 917 \\
\hline Ready-made clothing & 415 & 409 & 432 \\
\hline Hotel and Catering & 2,754 & 2,290 & 2,084 \\
\hline Processing industry & 1,540 & 1,304 & 1,152 \\
\hline Nursing and care-giving & 2,488 & 2,192 & 2,253 \\
\hline Civil engineering construction & 1,113 & 729 & 547 \\
\hline Coach builders and panel-beaters & 915 & 857 & 820 \\
\hline Textile industry & 175 & 188 & 193 \\
\hline Carpenters and cabinet-makers & 1,128 & 840 & 676 \\
\hline Bakery workers & 691 & 457 & 343 \\
\hline Hairdressing & 3,202 & 3,001 & 3,127 \\
\hline Butchers & 1,264 & 1,119 & 1,093 \\
\hline Installation engineers & 2,074 & 1,690 & 1,437 \\
\hline Total & 45,093 & 36,868 & 33,447 \\
\hline
\end{tabular}

Source: ROA 
Appendix 2. Estimation results of success rates and drop-out rates, average length of study of successful apprentices and drop-outs, and the proportion of apprentices who drop out within one Year, per supervisory board, 1980-1991 (with standard errors between parentheses

\begin{tabular}{|c|c|c|c|}
\hline $\begin{array}{l}\text { Supervisory } \\
\text { Board }\end{array}$ & $\begin{array}{l}\text { success } \\
\text { rate }\end{array}$ & $\begin{array}{l}\text { drop-out } \\
\text { rate }\end{array}$ & $\begin{array}{l}1 \text { year } \\
\text { drop-out } \\
\text { fraction }\end{array}$ \\
\hline Wholesale and retail & $\begin{array}{c}0.40 \\
(0.01)\end{array}$ & $\begin{array}{c}0.60 \\
(0.01)\end{array}$ & 0.84 \\
\hline Administration & $\begin{array}{c}0.43 \\
(0.05)\end{array}$ & $\begin{array}{c}0.57 \\
(0.05)\end{array}$ & 0.38 \\
\hline Road Transport & $\begin{array}{c}0.65 \\
(0.03)\end{array}$ & $\begin{array}{c}0.35 \\
(0.03)\end{array}$ & 0.00 \\
\hline Metals Industries & $\begin{array}{c}0.60 \\
(0.01)\end{array}$ & $\begin{array}{c}0.40 \\
(0.01)\end{array}$ & 0.21 \\
\hline Building trades & $\begin{array}{c}0.50 \\
(0.01)\end{array}$ & $\begin{array}{l}0.0 \\
(0.01)\end{array}$ & 0.29 \\
\hline Painters & $\begin{array}{c}0.53 \\
(0.01)\end{array}$ & $\begin{array}{c}0.47 \\
(0.01)\end{array}$ & 0.67 \\
\hline Vehicle and Bicycle trade & $\begin{array}{c}0.59 \\
(0.02)\end{array}$ & $\begin{array}{c}0.41 \\
(0.02)\end{array}$ & 0.28 \\
\hline Confectionary & $\begin{array}{c}0.62 \\
(0.01)\end{array}$ & $\begin{array}{c}0.38 \\
(0.01)\end{array}$ & 0.28 \\
\hline Electricians & $\begin{array}{c}0.38 \\
(0.02)\end{array}$ & $\begin{array}{c}0.62 \\
(0.02)\end{array}$ & 0.00 \\
\hline Health Care, technical trades & $\begin{array}{c}0.43 \\
(0.03)\end{array}$ & $\begin{array}{c}0.57 \\
(0.03)\end{array}$ & 0.00 \\
\hline Printing sector & $\begin{array}{c}0.68 \\
(0.01)\end{array}$ & $\begin{array}{c}0.32 \\
(0.01)\end{array}$ & 0.13 \\
\hline Ready-made clothing & $\begin{array}{c}0.44 \\
(0.02)\end{array}$ & $\begin{array}{c}0.56 \\
(0.02)\end{array}$ & 0.55 \\
\hline Hotel and catering & $\begin{array}{c}0.52 \\
(0.03)\end{array}$ & $\begin{array}{c}0.48 \\
(0.03)\end{array}$ & 0.74 \\
\hline Processing industry & $\begin{array}{l}0.53 \\
0.03\end{array}$ & $\begin{array}{l}0.48 \\
0.03\end{array}$ & 0.26 \\
\hline Nursing and care-giving & $\begin{array}{c}0.67 \\
(0.02)\end{array}$ & $\begin{array}{c}0.33 \\
(0.02)\end{array}$ & 0.28 \\
\hline Civil engineering construction & $\begin{array}{c}0.47 \\
(0.01)\end{array}$ & $\begin{array}{c}0.53 \\
(0.01)\end{array}$ & 0.47 \\
\hline Coach builders and panel-beaters & $\begin{array}{c}0.47 \\
(0.06)\end{array}$ & $\begin{array}{c}0.53 \\
(0.06)\end{array}$ & 0.71 \\
\hline Textile industry & $\begin{array}{c}0.61 \\
(0.03)\end{array}$ & $\begin{array}{c}0.39 \\
(0.03)\end{array}$ & 0.34 \\
\hline Carpenterrs and cabinet-makers & $\begin{array}{c}0.47 \\
(0.01)\end{array}$ & $\begin{array}{c}0.53 \\
(0.01)\end{array}$ & 0.49 \\
\hline Bakery workers & $\begin{array}{c}0.65 \\
(0.01)\end{array}$ & $\begin{array}{c}0.35 \\
(0.01)\end{array}$ & 1.00 \\
\hline Hairdressing & $\begin{array}{c}0.60 \\
(0.02)\end{array}$ & $\begin{array}{c}0.40 \\
(0.02)\end{array}$ & 0.60 \\
\hline Butchers & $\begin{array}{c}0.64 \\
(0.02)\end{array}$ & $\begin{array}{c}0.36 \\
(0.02)\end{array}$ & 0.37 \\
\hline Installation engineers & $\begin{array}{c}0.48 \\
(0.00)\end{array}$ & $\begin{array}{c}0.52 \\
(0.00)\end{array}$ & 0.32 \\
\hline
\end{tabular}

Source: ROA 
Appendix 3. Expected qualified outflow in absolute numbers, under the basic scenario, from the types of apprenticeships supervised by national boards, 1997 and 2001

\begin{tabular}{|c|c|c|c|}
\hline $\begin{array}{l}\text { Supervisory } \\
\text { Board }\end{array}$ & $1991 *$ & 1997 & 2001 \\
\hline Wholesale and retail & 1,173 & 1,237 & 1,618 \\
\hline Administration & 846 & 563 & 560 \\
\hline Road Transport & 620 & 448 & 612 \\
\hline Metals Industries & 2,290 & 1,705 & 2,100 \\
\hline Building trades & 1,807 & 1,072 & 1,319 \\
\hline Painters & 888 & 484 & 579 \\
\hline Vehicle and Bicycle trade & 2,194 & 1,306 & 1,764 \\
\hline Confectionary & 241 & 167 & 221 \\
\hline Electricians & 1,450 & 1,219 & 1,325 \\
\hline Health Care, technical trades & 111 & 168 & 227 \\
\hline Printing sector & 986 & 607 & 701 \\
\hline Ready-made clothing & 200 & 159 & 189 \\
\hline Hotel and catering & 1,467 & 998 & 1,207 \\
\hline Nursing and care-giving & 1,824 & 1,294 & 1,533 \\
\hline Civil engineering construction & 398 & 291 & 342 \\
\hline Coach builders and panel-beaters & 354 & 316 & 423 \\
\hline Textile industry & 58 & 93 & 117 \\
\hline Carpenters and cabinet-makers & 484 & 329 & 391 \\
\hline Bakery workers & 519 & 246 & 283 \\
\hline Hairdressing & 1,851 & 1,532 & 1,834 \\
\hline Butchers & 831 & 583 & 727 \\
\hline Installation engineers & 1,104 & 679 & 829 \\
\hline Total & 22,260 & 16,027 & 19,643 \\
\hline
\end{tabular}

Source: ROA 